\title{
Ethnoarchaeological Investigation of Affa in Udi local Government Area of Enugu
}

\author{
Ajoma Simon Okwoche ${ }^{1}$, Emeka Emmanuel Okonkwo', Inyabri Samuel Atam ${ }^{1}$, \\ Tawo Alfrd Oyong ${ }^{1}$, Onah Gabriel ${ }^{2}$ \\ ${ }^{1}$ Department of Archaeology and Tourism, Faculty of Art, University of Nigeria, Enugu, Nigeria \\ ${ }^{2}$ Cross River State Carnival Commission, Calabar, Nigeria
}

Email address:

jomosinee@gmail.com (A. S. Okwoche), emeka.okonkwo@unn.edu.ng (E. E. Okonkwo), samuelatam@gmail.com (Inyabri S.A), tawoalfred@gmail.com (T. A. Oyong), onahgab@yahoo.com (O. Gabriel)

\section{To cite this article:}

Ajoma Simon Okwoche, Emeka Emmanuel Okonkwo, Inyabri Samuel Atam, Tawo Alfred Oyong, Onah Gabriel. Ethnoarchaeological Investigation of Affa in Udi local Government Area of Enugu. Arabic Language, Literature \& Culture. Vol. 5, No. 4, 2020 , pp. 51-63. doi: $10.11648 /$ j.allc. 20200504.12

Received: June 30, 2020; Accepted: September 22, 2020; Published: December 31, 2020

\begin{abstract}
In the past, many archaeological researchers have targeted on unearthing the earliest origin of this technological know-how in the continent of Africa and its diversification or diffusion to different parts of the continent. Many of such researches have taken place in the Nsukka vicinity of Enugu, Nigeria. Some of the communities in the Nsukka subculture location have traces of this earliest technological know-how in their environment with little or no sizable answer to their origin. To this regard, this study is aimed at; studying one of the earliest technologies of Africans in this phase of Nigeria, conduct a reconnaissance and ethnographic research in Affa community, excavate an iron smelting web site in the community, decide the starting place of the humans and that of the iron smelting, and determine the cultural correlate of the extinct and extant societies of Affa. Ethnoarchaeology studies are useful to archaeology because it helps to draw analogy between the past and the present. The archaeologist uses ethnography to reconstruct past human culture by detailed study of the technology (tools), behaviour and environment of present day people in order to properly understand and reconstruct artifacts, eco-facts and features recovered from excavation. The study reveals that they were iron smelters.
\end{abstract}

Keywords: Excavation, Potsherd, Cultural Materials, Stratigraphy Level

\section{Introduction}

Iron smelting has been located to be amongst earliest technologies of Africans. It provided the earliest supply of raw substances for blacksmithing in the African continent and at the equal time shaped a foremost phase of the earliest monetary base of the people. In the past, many archaeological researchers have targeted on unearthing the earliest origin of this technological know-how in the continent of Africa and its diversification or diffusion to different parts of the continent. Many of such research have taken area in the Nsukka vicinity of Enugu, Nigeria [9]. Some of the communities in the Nsukka subculture location have traces of this earliest technological know-how in their environment with little or no sizable answer to their origin. To this regard, this study is aimed at; studying one of the earliest technologies of Africans in this phase of Nigeria, conduct a reconnaissance and ethnographic research in Affa community, excavate an iron smelting web site in the community, decide the starting place of the humans and that of the iron smelting, and determine the cultural correlate of the extinct and extant societies of Affa [6, 7]. Relevant lookup techniques were adopted for environment friendly learn about of this kind. They include; reconnaissance survey, ethnography, excavation and documentary sources.

\section{Study Area}

Udi is a Local Government Area in Enugu State, Nigeria. Its headquarters is in the city of Udi on the A232 highway. It has an area of Total $897 \mathrm{~km} 2$ (346 sq mi) and a total population of 234,002 as at the 2006 census. Coordinates: 
$6^{\circ} 19^{\prime} \mathrm{N} 7^{\circ} 26^{\prime} \mathrm{E}$ Coordinates: $6^{\circ} 19^{\prime} \mathrm{N} 7^{\circ} 26^{\prime} \mathrm{E}$. Affa is a town in Udi local government of Enugu state [9]. It is an abbreviation of Affamefune, Affa is located in northern part of enugu state and is densely populated and is bounded by Akpakume, Oghu, Umuoka, Egede, Umulungbe, Aku, Ochuma and Oghe.
The linage of Affa can be trace back to Ugwuadihi who beget Nogo and Nogo beget Achalluku and Achalluku married Ugwunye his wife who beget Nike and Egede also Achalluku beget Affa and Ukwume and Affa beget Ezeudene and okengwu Map of Enugu show showing Udi LGA.

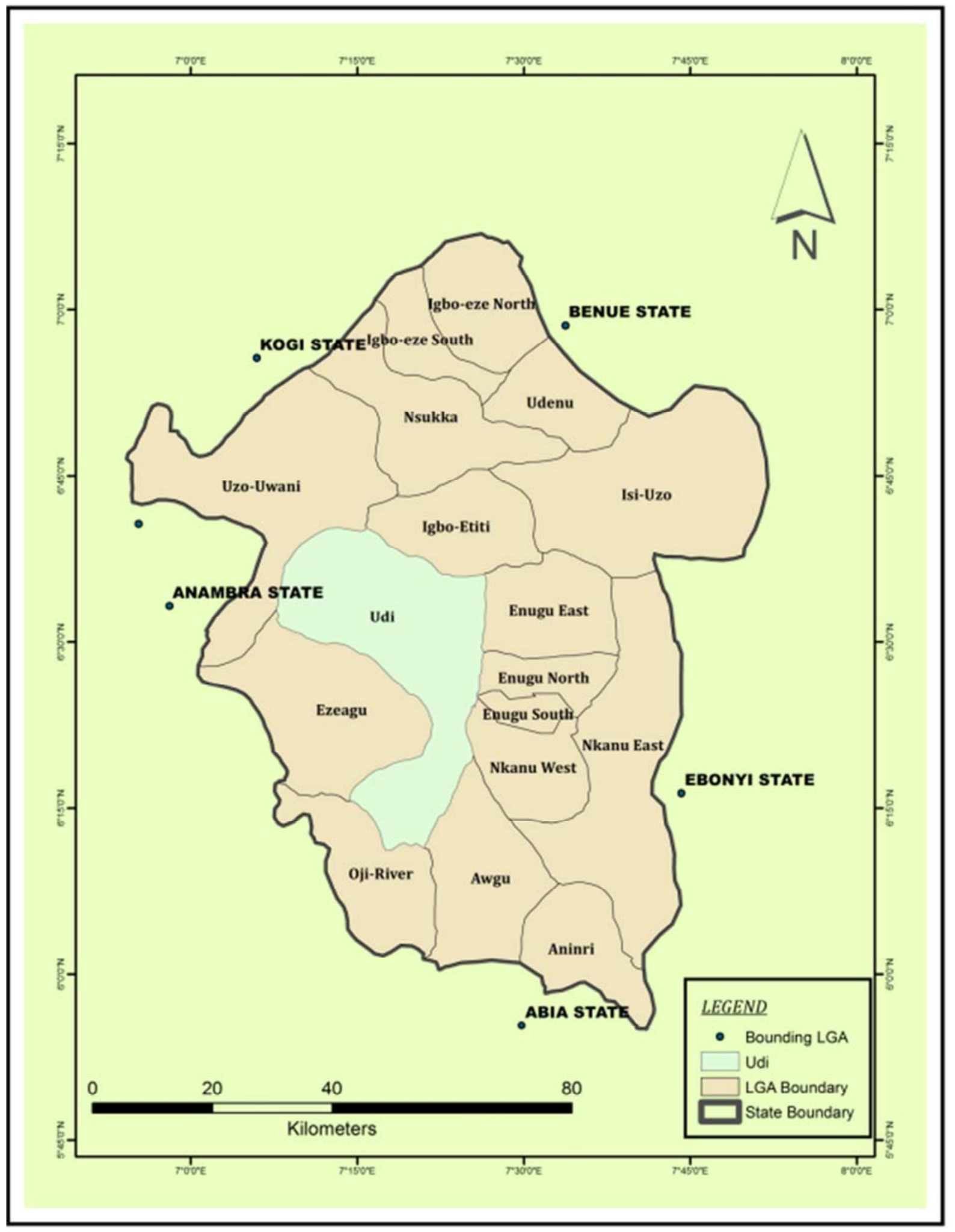

Figure 1. Source: Fieldwork/cartographicmapdigitalization, GIS lab arch/trmUNN. 
Map of Udi showing the study area or excavated site Affa (Amu-Wani1).

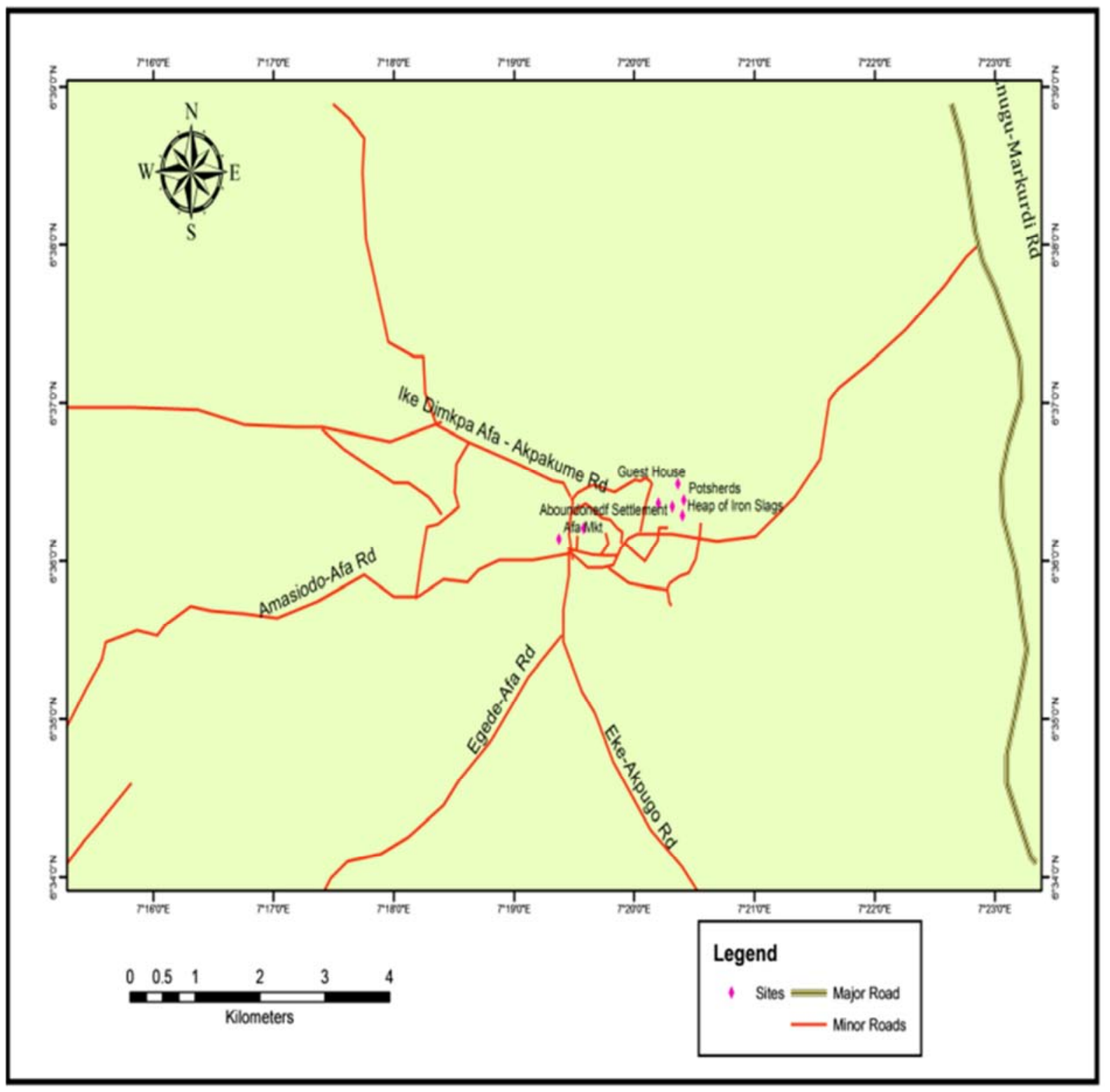

Figure 2. Source: Fieldwork/cartographicmapdigitalization, GIS lab arch/trmUNN.

\subsection{Method of Data Collection (Ethnoarchaeological Studies)}

Ethnoarchaeology studies are useful to archaeology because it helps to draw analogy between the past and the present. The archaeologist uses ethnography to reconstruct past human culture by detailed study of the technology (tools), behaviour and environment of present day people in order to properly understand and reconstruct artifacts, ecofacts and features recovered from excavation [10]. In Amuwani1, the ozor-Ezudele and onowu of the community were interviewed. Furthermore, through ethnographic studies, it was revealed that people came to the town in the olden days for iron smelting. The community is involved well in agriculture through planting of many crops and they have a popular festival known as Odo and ifejoku which has been greatly affected by the influence of Christianity. They celebrate their new yam in the month of August every year. They equally had some shrines/deities in the community such as Osin of Inoyi, ochu of Ikono, ibuzi of Amazalla, adobo of Amofia, Ebulogo of Ogor, Agbuyi of Umokoloma etc, these were worshiped because of the belief that they saved the lives of the people in the area. [11] But unfortunately Christianity has led to the abolishment of most of them. Finally the ethnographic study helped the fieldwork to determine the existence of iron smelting in Affa Umu-Wanil and some other background information which aided the process and progress of the field trip.

\subsection{The Datum Point}

In any systematic excavation, there is always need to have datum point from which other measurements of the site start. 
Datum point is a reference for future researchers to locate where an excavation has been done. It is usually represented using a feature [8]. Also the datum point is usually used to note the position of archaeological site after excavation. And features used as datum points should be permanent or long lasting features since the use of temporal features as a datum point might pose the archaeological site with the problem of being lost if the feature is removed [5]. However when no other external features could be found, the main house of $\mathrm{Mr}$. Francis Onowu electric pole and road was used as a substantive datum point.

The compound of Mr. Uwana was chosen amongst other compounds in the area due to the massive presence of heavy slag in cylindrical forms indicating the existence of industrial iron smelting site in the area in the past. Also in this compound, there are so many other iron smelting sites to be excavated but one was chosen and excavated due to the much presence of archaeological evidence on the surface and also its convenience to the family of Uwana, since some other sites are closer to the foundation of the house and might affect the house's foundation if excavated, through erosion menace after the excavation. The site was immediately adjacent the house of Mr. Francis (Onowu), within his compound.

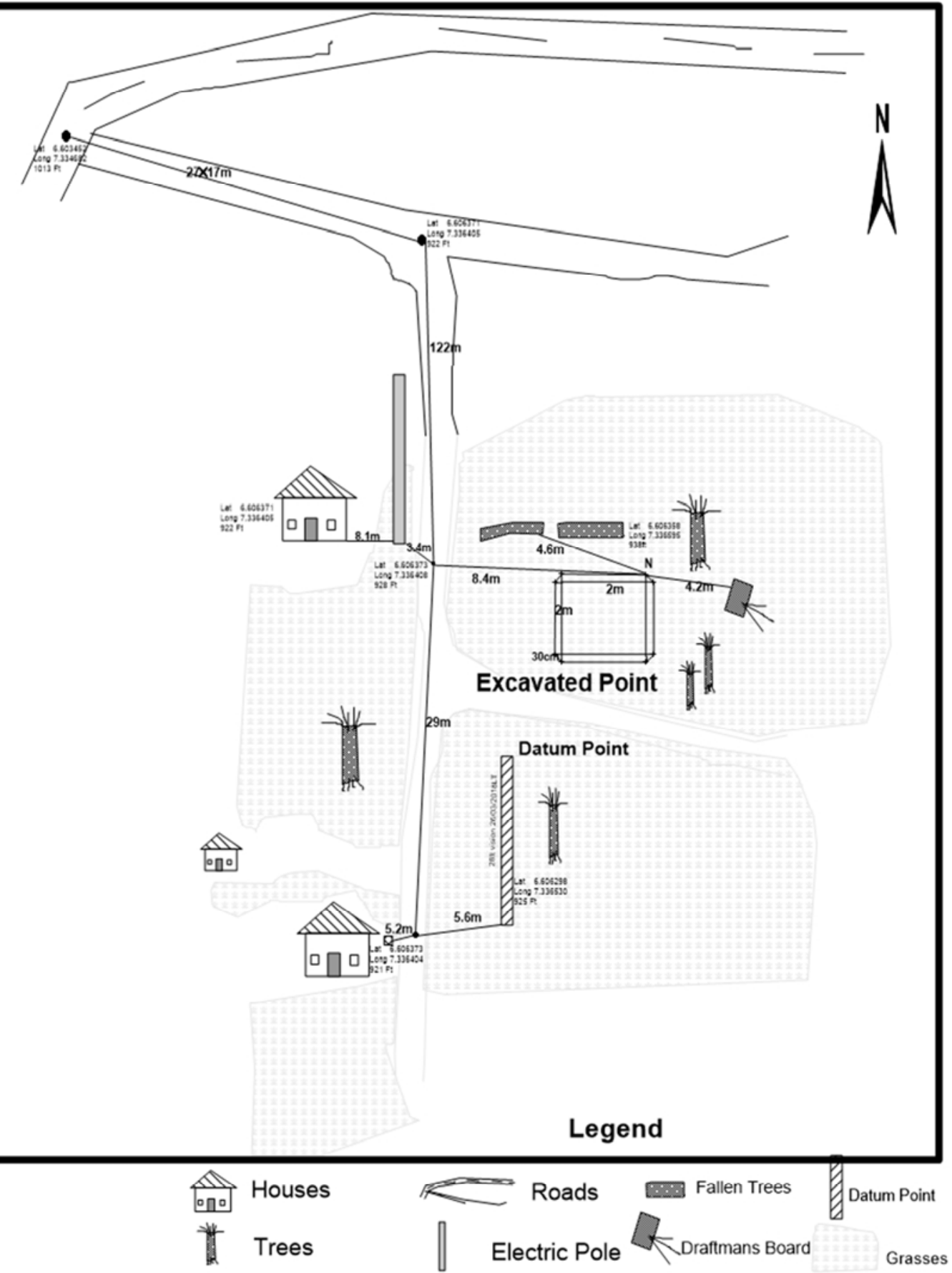

Figure 3. Site plan. 


\section{Result and Discussion}

\subsection{Reconnaissance}

"In search of evidence relating to the human past, the archaeologist has relied throughout the history of archaeology and has continued to rely principally on his eyes" [1]. Wilson [14] notes that archaeologists deal with what they could see; they dig where they could see a likely place or some tell-tale signs. However, reconnaissance can be defined as the preliminary survey used by archaeologists in determining archaeological potentials of an area. During reconnaissance, discoveries are made using human eyes which aid archaeological studies on any given area under archaeological investigations.

In Affa, the reconnaissance took place on the first day of the fieldwork, the site was transverse. At the Affa the Ozor (Ezeudene and Onowu) [11] in the community, was interviewed. Settlement patterns, architectural patterns of the village were equally observed and later to the house of $\mathrm{Mr}$. Richard Ugwuoke where presence of slag in large quantities, small and large ones was observed which indicated presence of iron smelting in the area in the past. There was also absence of large trees around the area showing that the old iron smelters in the area might have cut much of the trees in producing their charcoal for heating the iron ore during the smelting process. However, during ethnography, the people could not give good explanation with regards to the presence of the slag in the area, hence the slag were serving the following economic functions to the community; as cooking stands, as seats in their compounds and the village square, as bullets when broken into pieces and mixed with gun powder, as climbing steps to their bungalow houses, used in checking erosion by being placed around the basement of their houses, etc.

Furthermore, on the iron smelting in the community, it could not be ascertained whether the smelting was done by the Affa people, Egede, ( notable neighboring communities) etc, but it was done by early smelters in the community which would be established through articulate cultural linkages between the extinct and extant societies of the communities mentioned above. The reconnaissance photography are represented below.

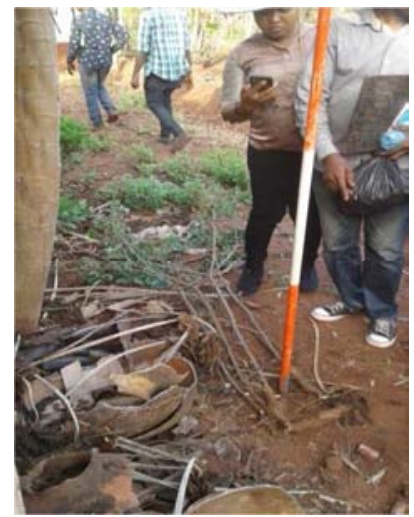

Figure 4. Cluster of potsherd.

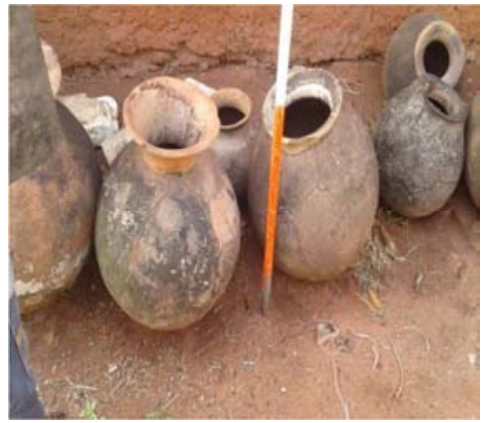

Figure 5. Cluster of pot use in storing water.

Why on our way excavation site reconnaissance was going on where we stop at Chief. Francis Ochinawanta's (Onowu), [11] house to study a cluster of potsherd and pots for collection of rainy water. It has a latitude of $6^{0} 36^{\prime} 22.9608^{\prime \prime}$ and longitude of $6^{0} 20^{\prime} 9.888^{\prime}$ " with elevation of 297.4848 above sea level. And that of pot used for collecting of rainy water and storage as well has latitude of $6^{0} 36^{\prime} 22.59^{\prime \prime}$ and longitude of $7^{0} 20^{\prime} 9.708$

\subsection{CINDER}

Cinder can be described as a burnt materials that result from incomplete combustion of coal or woods etc. A heap of cinder as a result of farming activities was study and the readings was also taking during reconnaissance. Thus cinder heap has a elevation of $299.3136 \mathrm{~m}$ above the sea level, latitude of $6^{0} 36^{\prime} 23.4$ " and longitude of $7^{0} 20^{\prime} 16.494$ " height $1.43256 \mathrm{~m}$, width $5.83 \mathrm{~m}$ and length of $6.60 \mathrm{~m}$.

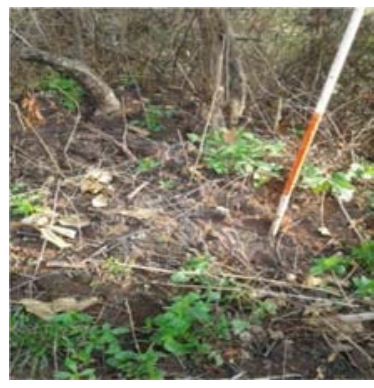

Figure 6. A heap of cinder.

\subsection{Abandon Settlement}

An abandoned settlement is a village or a house that has, for some reason, been deserted. In many countries, and throughout history, thousands of villages or hoses have been deserted for a variety of causes. Abandonment of villages is often related to epidemic, famine, war, climate change, environmental destruction, or deliberate clearances. In AmuWani1 reconnaissance process abandon settlement was noted as well. It has latitude of $6^{\circ} 36^{\prime} 22.6008^{\prime}$ and longitude of $7^{\circ} 20^{\prime} 9.8412^{\prime}$ and elevation of $294.4368 \mathrm{~m}$ above sea level. 


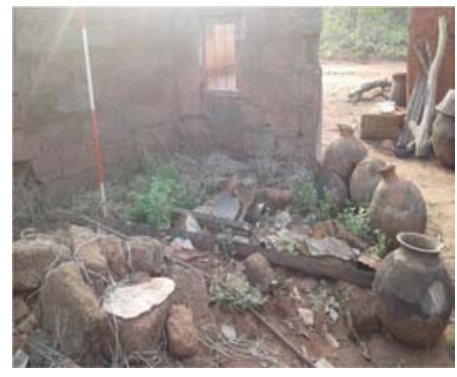

Figure 7. Abandon settlement.

\subsection{Mapping of the Site}

Key to successful excavation of an archaeological site is accurate mapping. The archaeological crew arrives on-site and systematically records location, topography, and surface artifact collections. There are no precise formulas for proper mapping since unique site situations require creative solutions [3]. The site was adjacent onowu's compound, right opposite the road and electric pole. Before any excavation is begun at a site, the archaeologist must prepare a survey map of the site. Site mapping may be as simple as a sketch of the site boundaries, or as complex as a topographic map, complete with details about vegetation, artifacts, structures, and features on the site. By recording the presence of artifacts on the site, the site map may reveal information about the way the site was used, including patterns of occupational use. Contour maps may shed light on ways in which more recent environmental activity may have changed the original patterns of use. In cases where structural remains are visible at a site, the site map can provide a basis for planning excavations. These processes and materials are all involved in archaeological mapping.

\subsection{The Grid System}

This could be defined as the practice of dividing a site into squares to enable for easy recording of features and objects excavated during systematic excavation. Normally a square trench is cut within each grid square and separated by a baulk from each neighbouring trench to easy the process [2]. However, in archaeology there are two types of gridding; the finite and union grid. While finite grid is used on a limited area of excavation site, union grid is used on a large area of excavation site. Also while the finite grid system uses a oneby-one $\mathrm{cm}$ interval, the union grid system is using a 10-by-10 $\mathrm{cm}$ interval or even more depending on the area of excavation coverage [3]. In the excavation at Umu-Wanil finite grid system was used due to the limited nature of the site to be excavated. Effective grid system helped in the systematic collection of artefacts, location of materials, getting the contour of the materials, and limiting the area of the excavation.

In making the grid, a compass was set to find the cardinal points so as to locate the position of the North Pole (N-P). After getting the N-P, a peg was used at the North East (N-E) of the proposed wall. From that N-E peg, using Pythagoras Theorem, a Tape was used to get $3 \mathrm{~m}$ to the North West $(\mathrm{N}-\mathrm{W})$ of the site and it was pegged, from N-W peg to the $4 \mathrm{~m}$ to the South West (S-W) of the site and it was pegged. From the S$\mathrm{W}$ the pegging diagonally returned to the N-E peg to get the Hypotenuse at $5 \mathrm{~m}$. i.e.

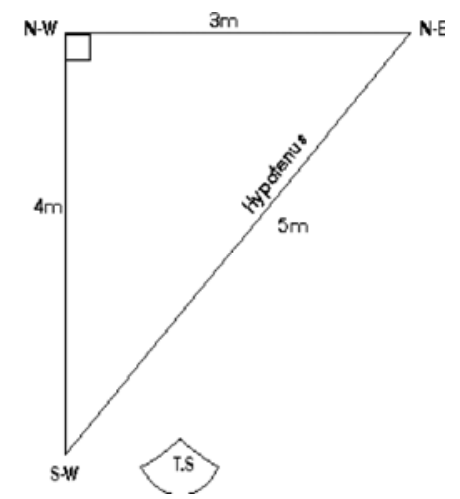

Figure 8. Showing the diagonal $N-W / N-E$.

After which the right angle was indicated. The marking went further $3 \mathrm{~m}$ from south-west (S-W) to get the south-east (S-E), from this pole returned $4 \mathrm{~m}$ to the original N-E peg. ie

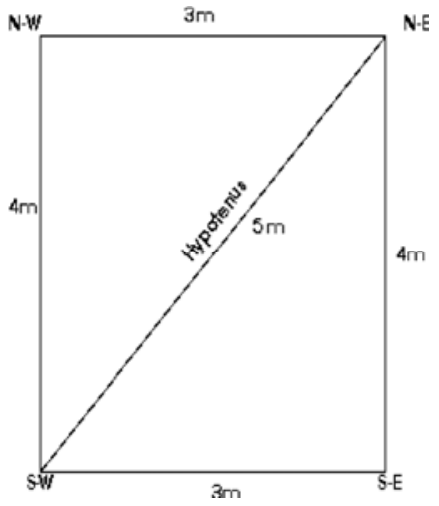

Figure 9. Showing 3,4,5 method of griding.

Then one-by-one meters was measured from the north-east peg to the north-west, to the south-west peg, to the south-east peg and back to the north-east peg. Pins were put at each of the meters as shown below;

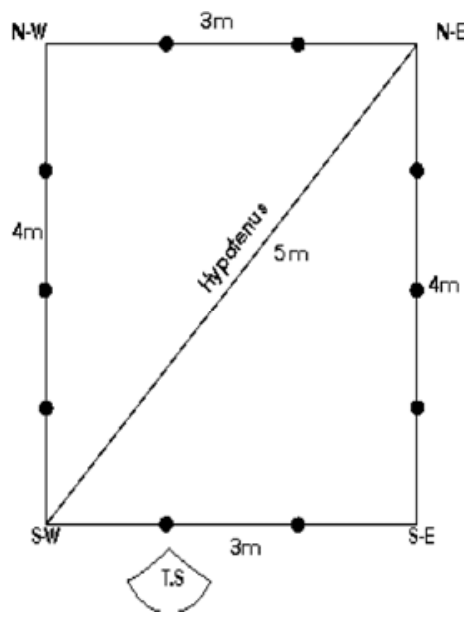

Figure 10. Showing one-by-one meter. 
Furthermore, using pins to indicate the one-by-one meters, pegs were used to replace the pins after which ropes were used to connect the pegs and the grids were numbered into twelve (12) sub-grids. Is represent below
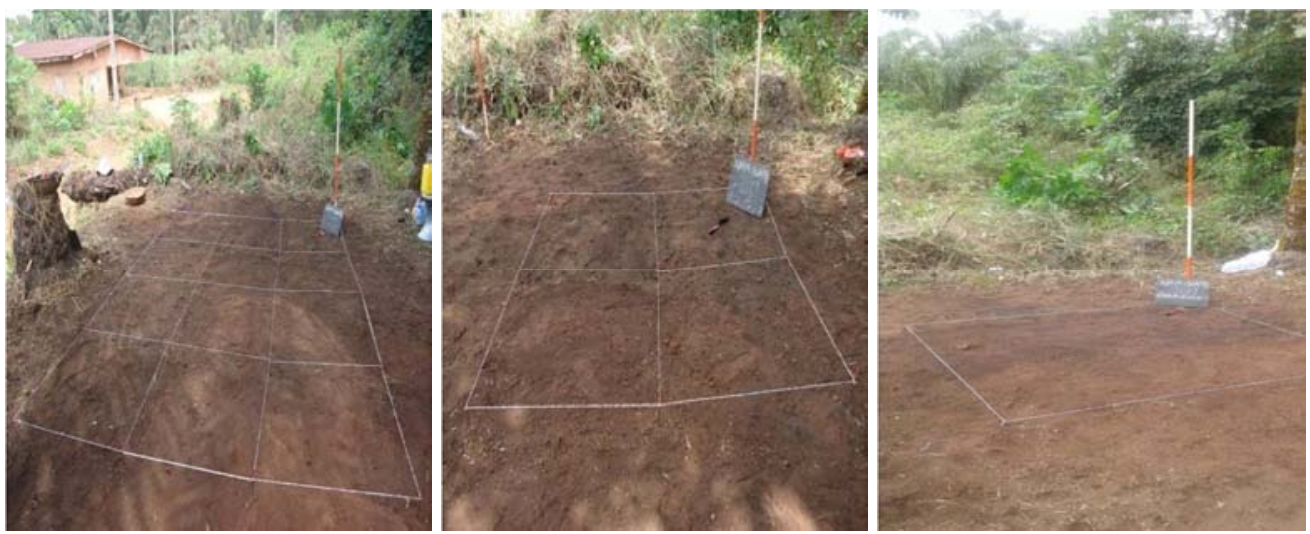

Figure 11. Griding (a) 2,4,5,6 trench (b) trench (c).

\section{The Excavation}

Excavation is the major means by which archaeologists gather data about the past mainly from beneath the ground surface $[1,2]$ notes that in archaeological excavation, the deposits are perforce dug away, and could be destroyed. But an excavation can only justify its destruction if done meticulously and finds preserved, accurate information recorded afterwards, etc. Hester et al [4] posits that immediately an area of a site is chosen for archaeological excavation, archaeologists must choose the appropriate excavation method to be used. The choice will depend on the site under investigated and on the specific goal to be achieved at the end of the practice. [3, 13]

Having chosen or selected the two-by-two meter square to excavate, the digging was started and the site was named "Amu-Wanil 2019". 0-20cm was chosen as the first spit level but later extended to $0-40 \mathrm{~cm}$ and continued from $40 \mathrm{~cm}$ $-220 \mathrm{~cm}$. and from $220-240 \mathrm{~cm}$ (testspit 12) was our sterile layers where there were no cultural materials any longer. A sample bag was named and used to collect all the collections from this level. Below are the pictures of the testspit from 0$20 \mathrm{~cm}$ and $20-240 \mathrm{~cm}$.

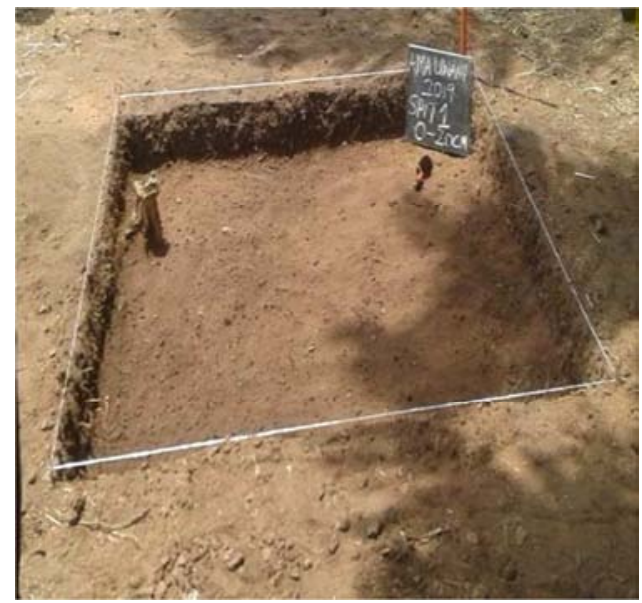

Figure 12. $(0-20 \mathrm{~cm}$ testspit 1$)$.

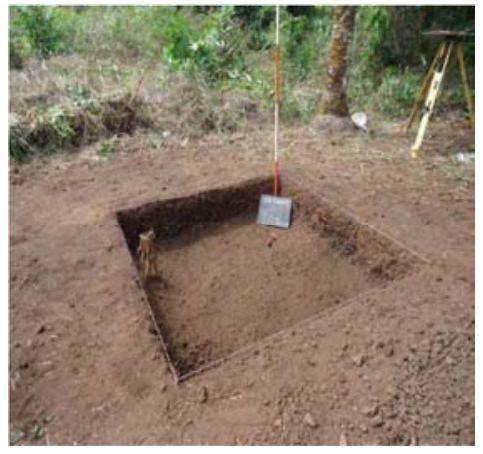

Figure 13. 20-40 testspit 2.

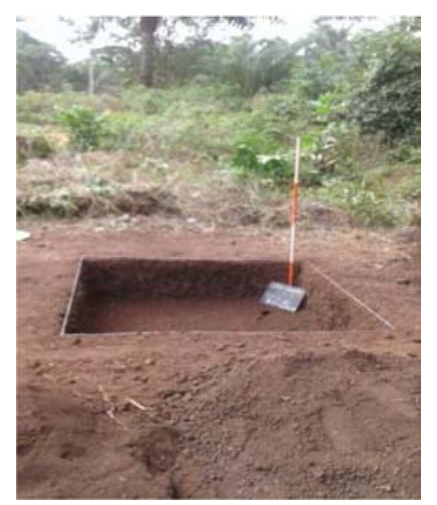

Figure 14. 40-60 testspit 3.

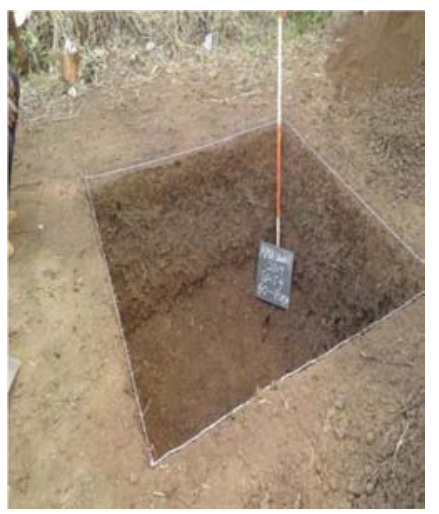

Figure 15. 60-80, testspit 4. 


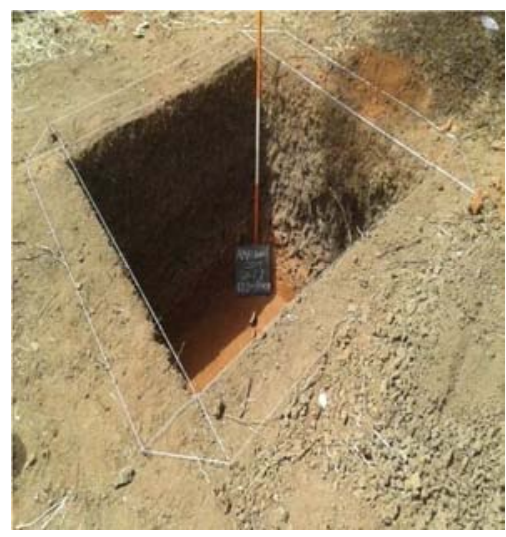

Figure 16. 80-100 testspit 5.

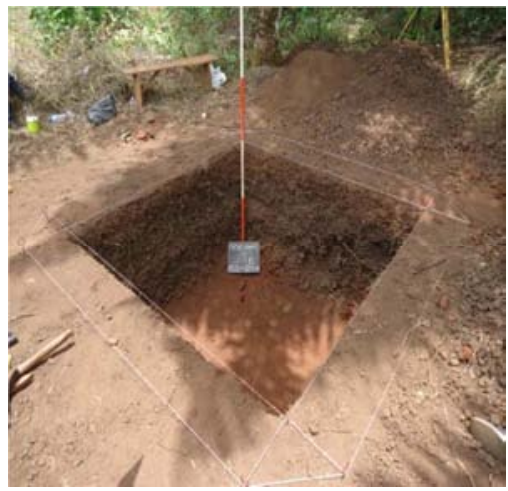

Figure 17. 100-120 testspit 6.

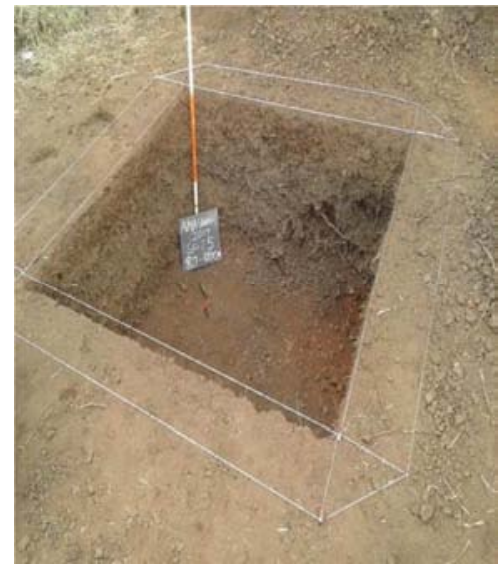

Figure 18. 120-140 testspit 7.

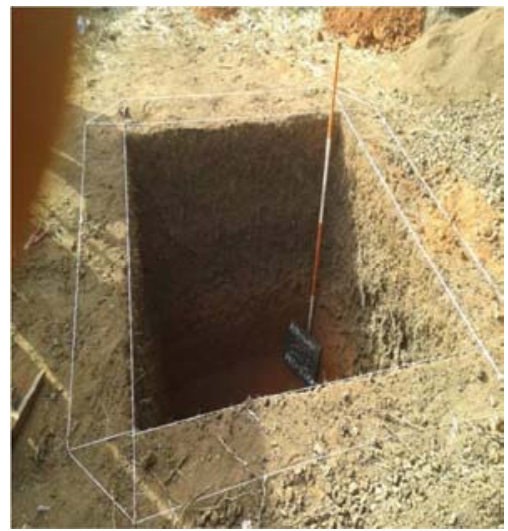

Figure 19 140-160 testspit 8.

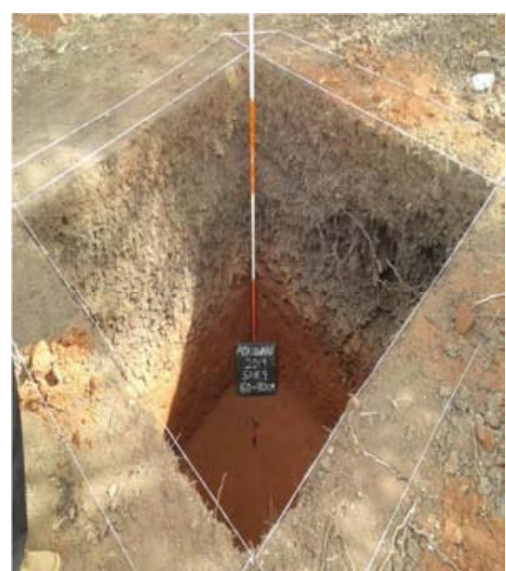

Figure 20. 160-180 testspit 9.

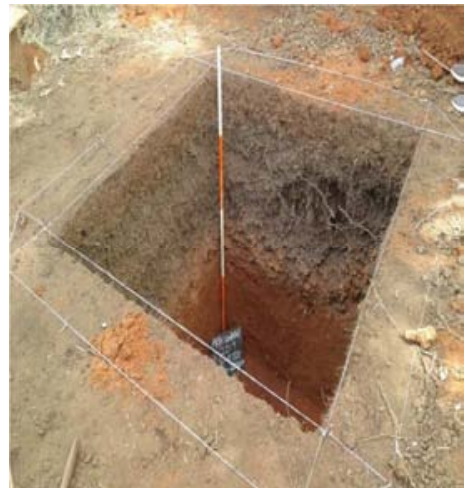

Figure 21. 180-200 testspit 10.

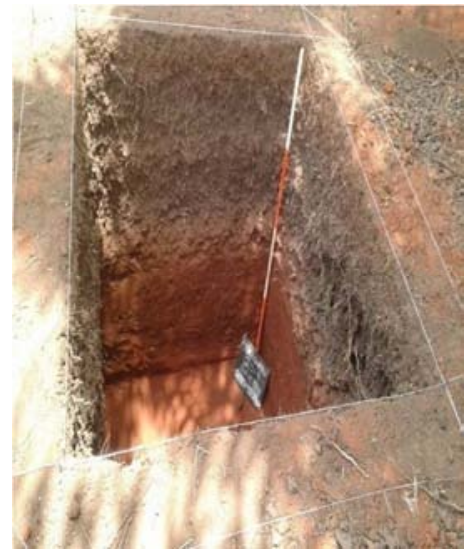

Figure 22. 200-220 testspit 11.

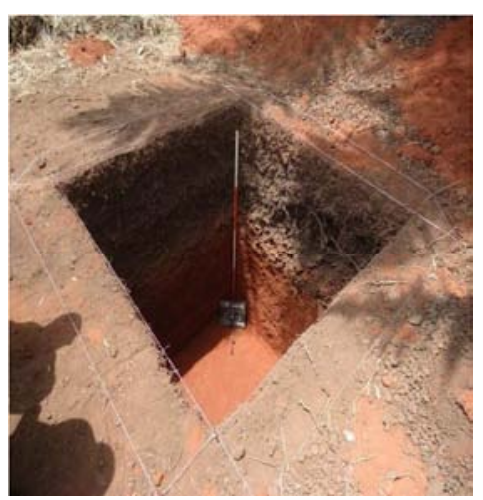

Figure 23. 220-240- testspit 12. 


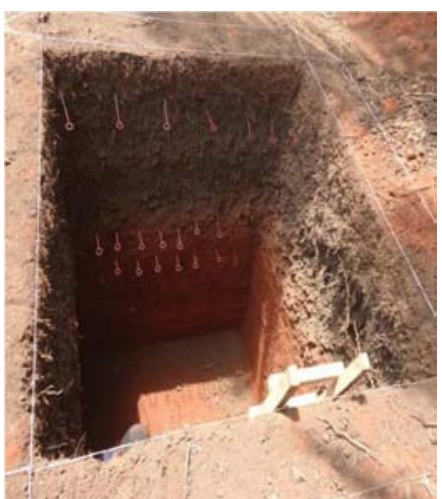

Figure 24. Stratigraphy.

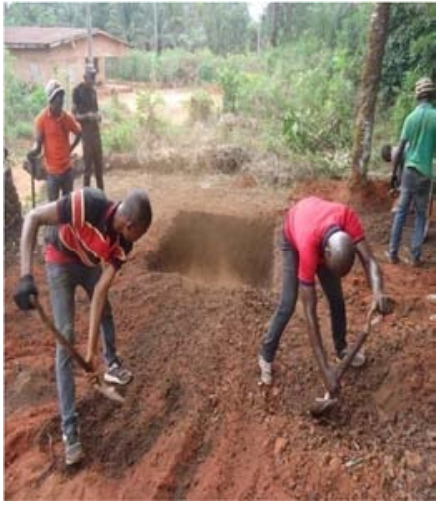

Figure 25. Covering of the trench.

\section{Stratigraphy}

Archaeological stratigraphy is the archaeological evaluation of the temporal and positional meaning of the observe strata. In stratigraphy analysis archaeologist combines the law of superposition with consideration of context [1]. If archaeologist can demonstrate primary context with reasonable assurance the deposit may be assumed to follow that of the strata. In this way a stratigraphy sequence may be establish [1]. Stratigraphy thus deal with the study of sequences of deposits in a site. It also refers to the level (natural or arbitrary) that are excavated [4].

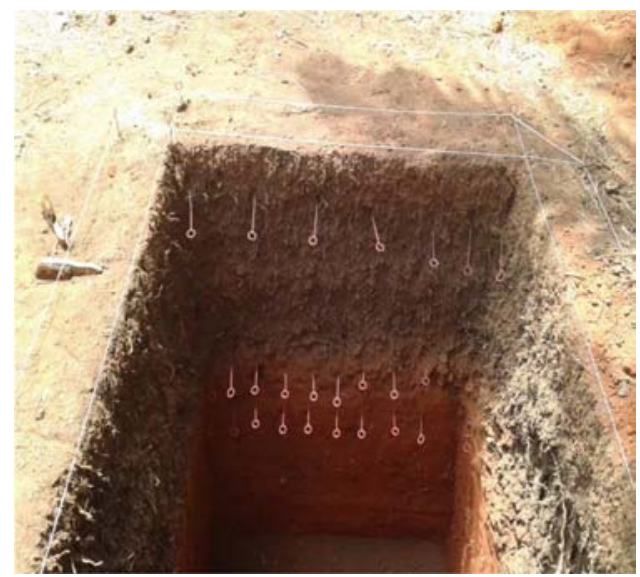

Figure 26. Stratigrahy reading.

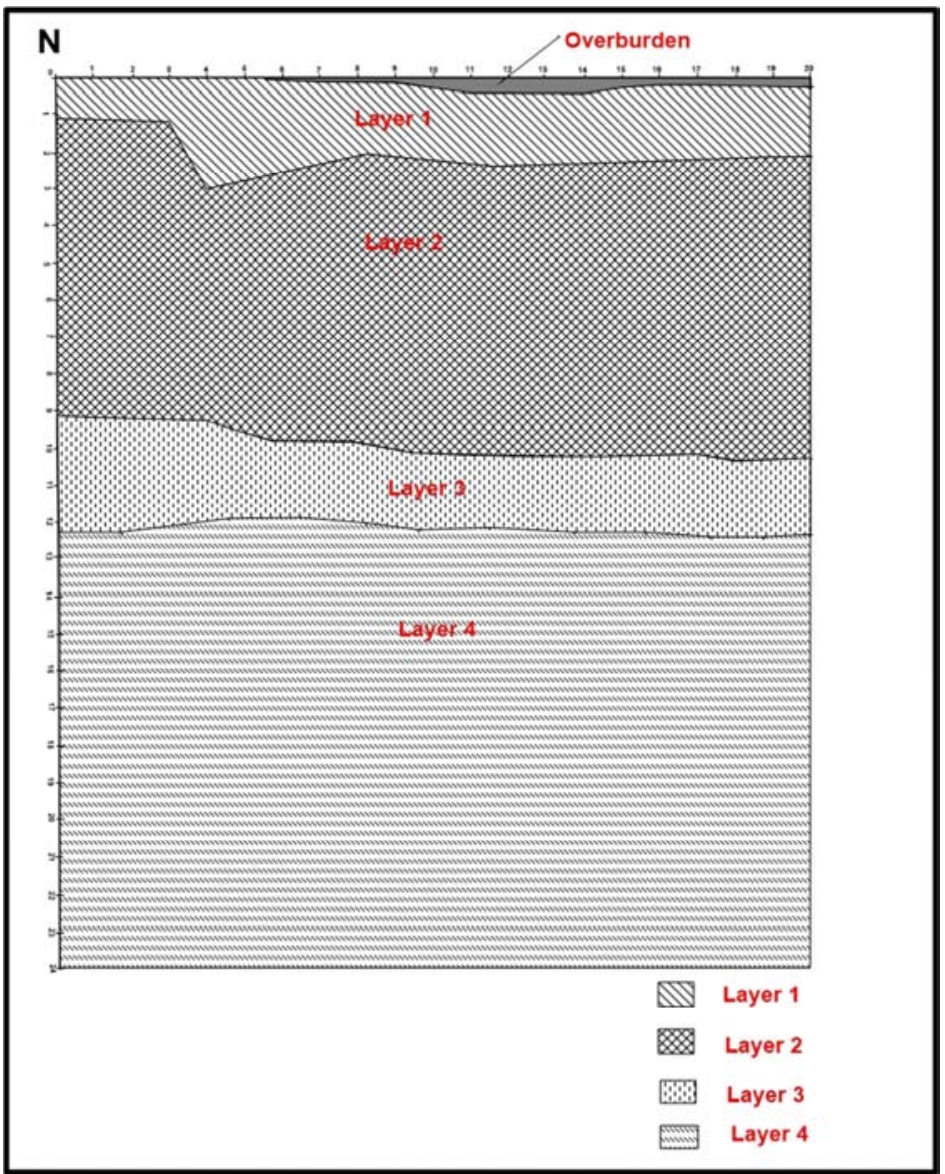

Figure 27. Stratigrahy graph. 


\section{Analysis of Cultural Materials from Each Testspit}

Data gather will be analyze categorically and according to how the excavation is been done in the field.

During reconnaissance 24 cultural materials were collected at Amu-Wani, during the excavation properly so many collections were made from the spit levels dug. A total of six hundred and fifteen (615) cultural materials were recovered out of which potsherd 260, charcoal 17, stone 27, tuyere 21, bake clay 101, slag 141, palm kennel 30, metal object 2, cinder 11 , shell 2, ceramic 2 and glass. This is represented in the table below;

Table 1. Analysis of cultural materials recovered.

\begin{tabular}{|c|c|c|c|c|c|c|c|c|c|c|c|c|c|c|c|}
\hline $\mathbf{S} / \mathbf{N}$ & Items & Potsherds & $\begin{array}{l}\text { Baked } \\
\text { clay }\end{array}$ & Slag & Charcoal & Stone & $\begin{array}{l}\text { Palm } \\
\text { kernel } \\
\end{array}$ & $\begin{array}{l}\text { Metal } \\
\text { objects }\end{array}$ & Cinder & $\begin{array}{l}\text { Snail } \\
\text { shell }\end{array}$ & $\begin{array}{l}\text { Tuyére } \\
\text { nozzle }\end{array}$ & Glass & $\begin{array}{l}\text { Glazed } \\
\text { ceramics }\end{array}$ & Total & Percentage \\
\hline 1 & Reconnaissance & 21 & - & - & - & - & - & 2 & 1 & - & - & - & - & 24 & 3.902 \\
\hline 2 & Surface collection & 7 & - & 67 & - & 1 & 4 & - & - & 2 & - & - & 2 & 83 & 13.496 \\
\hline 3 & Spit $1(0-20 \mathrm{~cm})$ & 5 & 8 & 6 & 3 & 1 & 25 & - & - & - & - & - & - & 48 & 7.804 \\
\hline 4 & Spit $2(20-40 \mathrm{~cm})$ & 33 & 14 & - & - & 4 & 1 & - & 2 & - & - & - & - & 54 & 8.780 \\
\hline 5 & Spit $3(40-60 \mathrm{~cm})$ & 32 & 8 & 5 & - & - & - & - & - & - & - & - & - & 45 & 7.317 \\
\hline 6 & Spit $4(60-80 \mathrm{~cm})$ & 59 & 43 & 10 & 4 & 13 & - & - & 7 & - & 5 & - & - & 141 & $\begin{array}{l}22.927 \\
22.927\end{array}$ \\
\hline 7 & Spit $5(80-100 \mathrm{~cm})$ & 7 & - & 10 & - & 1 & - & - & - & - & 1 & 1 & - & 20 & 3.252 \\
\hline 8 & Spit $6(100-120 \mathrm{~cm})$ & 9 & 19 & 1 & 1 & 2 & - & - & - & - & 11 & - & - & 43 & 6.831 \\
\hline 9 & Spit $7(120-140 \mathrm{~cm})$ & 8 & 7 & 1 & 2 & 1 & - & - & 1 & - & 3 & - & - & 23 & 3.740 \\
\hline 10 & Spit $8(140-160 \mathrm{~cm})$ & 5 & - & 2 & 3 & - & - & - & - & - & - & - & - & 10 & 1.626 \\
\hline 11 & Spit $9(160-180 \mathrm{~cm})$ & 13 & 1 & 8 & 2 & - & - & - & - & - & - & - & - & 24 & 3.902 \\
\hline 12 & Spit $10(180-200 \mathrm{~cm})$ & 34 & 1 & 10 & 1 & 1 & - & - & - & - & - & - & - & 47 & 7.642 \\
\hline \multirow{2}{*}{13} & Total & 260 & 101 & 141 & 17 & 27 & 30 & 2 & 11 & 2 & 21 & 1 & 2 & 615 & \\
\hline & Percentage & 42.276 & 16.422 & 22.296 & 2.764 & 4.395 & 4.878 & 0.325 & 1.788 & 0.325 & 3.414 & 0.162 & 0.325 & - & 100 \\
\hline
\end{tabular}

\subsection{Pottery Analysis}

Pottery has been discovered to be amongst the more relevant artefacts to archaeologists in the reconstruction of the past. However in Amu-Wani1, 260 pieces of potsherds were collected from all the Spit Level (0-220) of the excavation. Rim has a total of 22 pieces; neck 38 and the body 200 making the total of 260 potsherd.

\subsection{Summary of Pottery Part from Test Spit}

Table 2. Analysis of potsherd.

\begin{tabular}{|c|c|c|c|c|c|c|}
\hline $\mathbf{s} / \mathbf{n}$ & Pottery part & Body & Rim & Neck & Total & $\%$ \\
\hline 1 & Reconnaissance & 15 & 2 & 4 & 21 & 8.077 \\
\hline 2 & Surface collection & 5 & 1 & 1 & 7 & 2.692 \\
\hline 3 & Spit1 $(0-20) \mathrm{cm}$ & 3 & 2 & & 5 & 1.923 \\
\hline 4 & Spit2(20-40)cm & 24 & 1 & 8 & 33 & 12.692 \\
\hline 5 & Spit3(40-60)cm & 27 & 1 & 4 & 32 & 12.307 \\
\hline 6 & Spit4(60-80)cm & 48 & 3 & 8 & 59 & 22.692 \\
\hline 7 & Spit5(80-100)cm & 5 & 1 & 1 & 7 & 2.692 \\
\hline 8 & Spit6(100-120)cm & 8 & 1 & & 9 & 3.461 \\
\hline 9 & Spit7(120-140)cm & 4 & & 4 & 8 & 3.077 \\
\hline 10 & Spit8(140-160)cm & 1 & 4 & & 5 & 1.923 \\
\hline 11 & Spit9(160-180)cm & 11 & & 2 & 13 & 5 \\
\hline 12 & Spit10(180-200)cm & 21 & 8 & 5 & 34 & 13.077 \\
\hline 13 & Spit11(200-220)cm & 25 & 1 & 1 & 27 & 10.387 \\
\hline Total & & 200 & 22 & 38 & 260 & 100 \\
\hline$\%$ & & 76.923 & 8.462 & 14.615 & 100 & \\
\hline
\end{tabular}




\subsubsection{Analysis of Decorative Motif of Potsherd from Test Spit}

Table 3. Analysis of decorative motif of potsherd.

\begin{tabular}{|c|c|c|c|c|c|c|c|c|c|}
\hline $\mathbf{s} / \mathbf{n}$ & & Burnishing & Maize cob & Rope roulette & Net impression & Incision & Composition & Total & $\%$ \\
\hline 1 & Reconnaissance & 4 & 5 & 2 & 5 & 2 & 3 & 21 & 1.730 \\
\hline 2 & Surface collection & 3 & 1 & 3 & & & & 7 & 2.692 \\
\hline 3 & Spit1(0-20)cm & 2 & & 2 & & & 1 & 5 & 1.923 \\
\hline 4 & 2 & 6 & 16 & 4 & 4 & & 3 & 33 & 12.692 \\
\hline 5 & 3 & 3 & 7 & 2 & 17 & 2 & 1 & 32 & 12.307 \\
\hline 6 & 4 & 5 & 30 & 12 & 1 & 3 & 8 & 59 & 22.692 \\
\hline 7 & 5 & 2 & & 3 & & & 2 & 7 & 2.692 \\
\hline 9 & 7 & 2 & 1 & 4 & & & 1 & 8 & 3.076 \\
\hline 10 & 8 & 2 & 1 & 1 & 1 & & & 5 & 1.923 \\
\hline 11 & 9 & 4 & 2 & 1 & 3 & & 3 & 13 & 5 \\
\hline 12 & 10 & 14 & 7 & 3 & 1 & 3 & 6 & 34 & 13.076 \\
\hline \multirow[t]{3}{*}{13} & 11 & 11 & 8 & & 4 & 3 & 1 & 27 & 10.384 \\
\hline & Total & 60 & 70 & 42 & 36 & 13 & 30 & 260 & \\
\hline & $\%$ & 23,077 & 30.386 & 16.153 & 13.846 & 5 & 11.538 & 100 & \\
\hline
\end{tabular}

\subsubsection{Decorative Motif of Potsherd Base on Quantity and Percentage (\%) of Occurrence}

Table 4. Decorative motif of potsherd base on quantity and percentage (\%) of occurrence.

\begin{tabular}{llll}
\hline $\mathbf{s} / \mathbf{n}$ & Decoration & Qty of occurrence & \% of occurrence \\
\hline 1 & Burnishing & 60 & 23.077 \\
2 & Net impression & 36 & 13.846 \\
3 & Rope roulette & 42 & 16.153 \\
4 & Maize cob & 79 & 30.386 \\
5 & Incision & 13 & 5.0 \\
6 & Composite & 30 & 11.538 \\
& Total & 260 & 100 \\
\hline
\end{tabular}

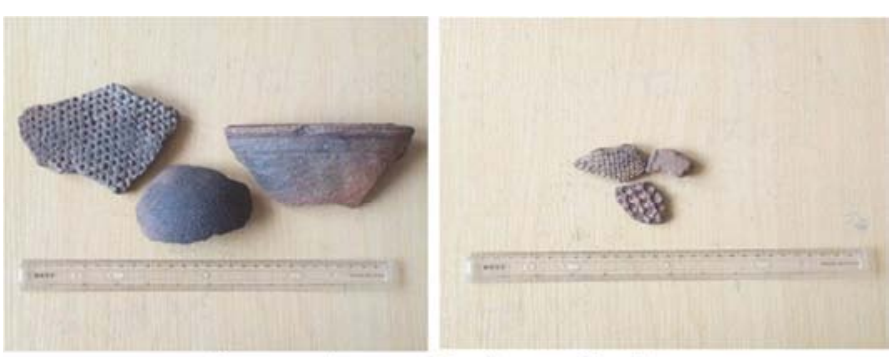

Reconnaissance Surface collection

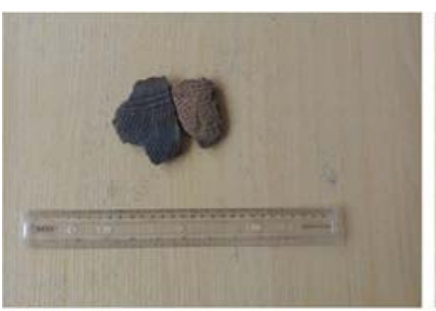

Spit 1

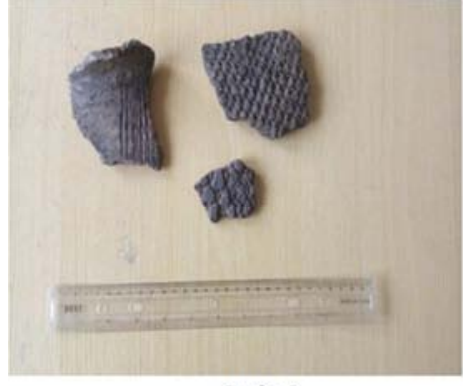

Spit 3

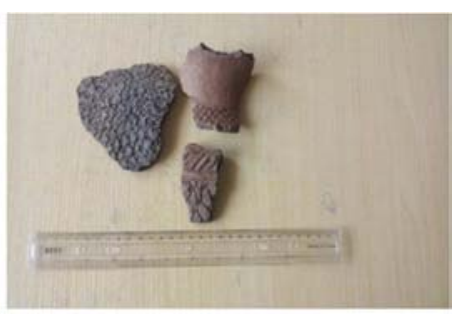

Spit 2

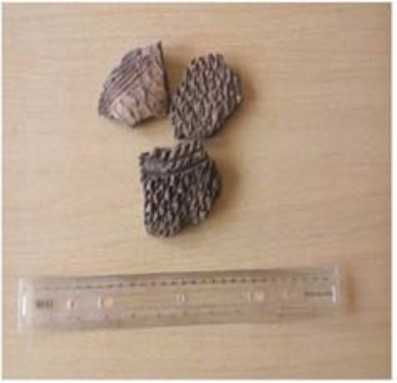

Spit 4 


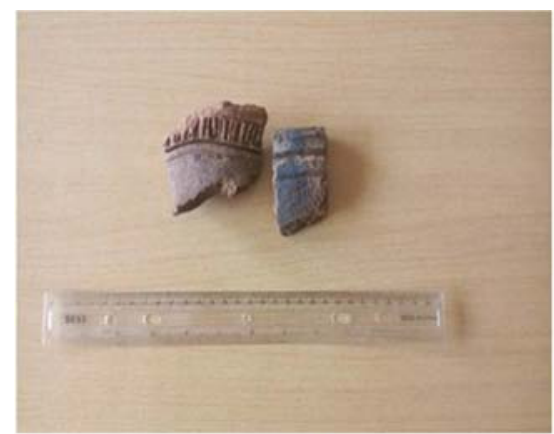

Spit 5

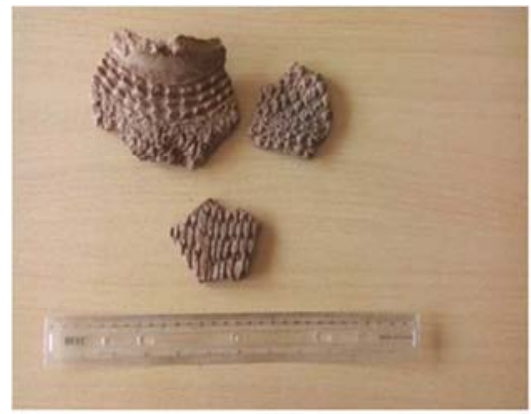

Spit 7

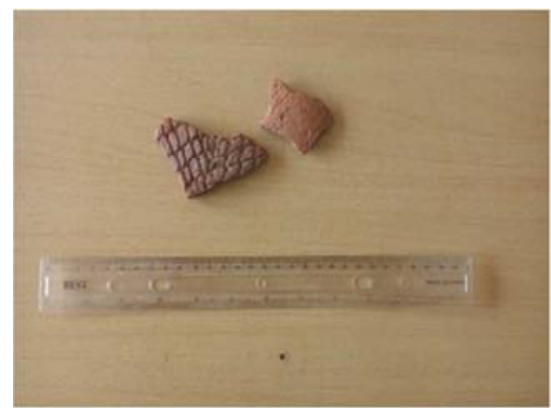

Spit 9

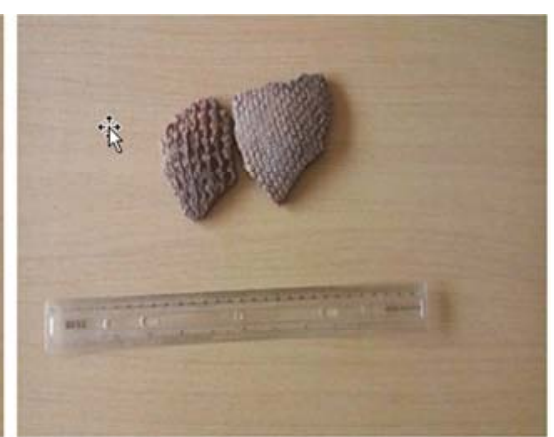

Spit 6

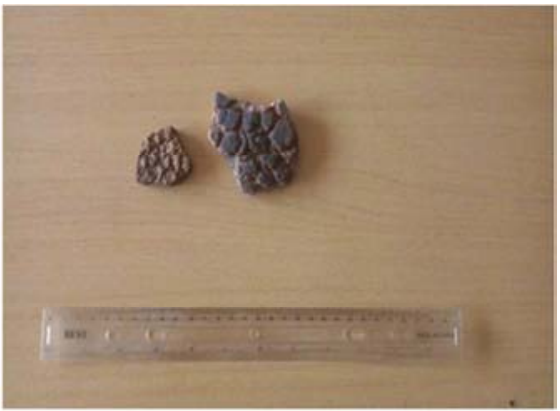

Spit 8

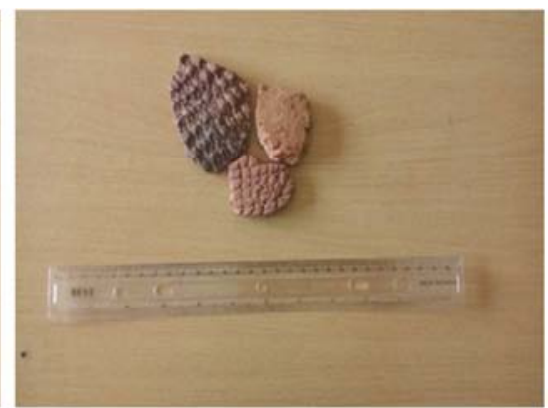

Spit 10

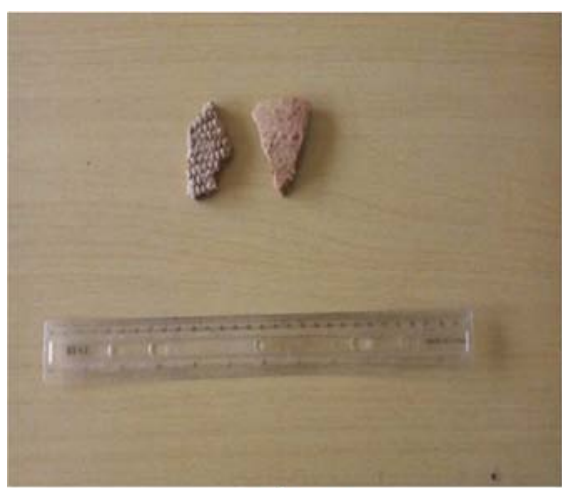

Spit 11

Layer1

Figure 28. Portsherd recover from reconnaissance to spit 11.

Table 5. Source; munsellcolorchart7.5yrdiagram.

\begin{tabular}{lllll}
\hline $\mathbf{s} / \mathbf{n}$ & $\mathbf{1}$ & $\mathbf{2}$ & $\mathbf{3}$ & $\mathbf{4}$ \\
\hline & Black & Dark brown & Dark brown \\
\hline
\end{tabular}




\subsection{Stratigraphy Measurement of the Strata}

Table 6. Stratigraphy measurement of the strata.

\begin{tabular}{|c|c|c|c|c|c|c|c|}
\hline \multicolumn{2}{|c|}{ Layer1 $(\mathrm{cm})$} & \multicolumn{2}{|c|}{ Layer $2(\mathrm{~cm})$} & \multicolumn{2}{|c|}{ Layer $3(\mathrm{~cm})$} & \multicolumn{2}{|c|}{ Overburden (cm) } \\
\hline 10 & 10.6 & 14 & 93 & 18 & 121 & $0-56$ & 0 \\
\hline 30 & 11.5 & 40 & 94 & 44 & 117 & 56 & 1.3 \\
\hline 40 & 39.9 & 58 & 97 & 66 & 120 & 70 & 1.3 \\
\hline 84 & 20.8 & 76 & 99 & 82 & 121 & 90 & 1.2 \\
\hline 117 & 25 & 94 & 101 & 96 & 123 & 110 & 1.5 \\
\hline 150 & 23 & 108 & 103 & 115 & 122 & 130 & 2 \\
\hline \multirow[t]{6}{*}{189} & 23 & 127 & 103 & 138 & 123 & 140 & 2 \\
\hline & & 168 & 101 & 174 & 124 & 160 & 1 \\
\hline & & 180 & 104 & 189 & 124 & 170 & 2 \\
\hline & & & & & & 180 & 2.1 \\
\hline & & & & & & 190 & 2.6 \\
\hline & & & & & & 200 & 2 \\
\hline
\end{tabular}

\subsection{Summary and Recommendation}

However having sourced for data in various sources i.e. reconnaissance, ethnography, excavation and secondary sources, and their subsequent analysis, some preliminary conclusions were made. It is obvious that the existing society of the area have little or no knowledge of iron smelting in the area. This point to the fact that their founder may not have engaged in the iron smelting technology in the area in the past. The cultural understanding of the present society of Affa has nothing in common with tradition of iron smelting as found in other iron smelting societies [7]. And in pottery making according to the informant she said the Amu-Wani1 in Affa community don't engage in pottery making because of its fragile nature [12]. Through the ethnographic study of Affa.. The understanding of the excavated potteries from the site is an indication that the people living in the area are of Neolithic age since most of the potsherds did not show any sign of wear and tear suggesting that the potsherds are relatively young in nature. Also the decorations on the potsherds are also not different from the general.

\section{References}

[1] Andah, B. W. and A. I. Okpoko, (1994). Practicing archaeology in Africa. Ibadan: Wisdom Publishers Limited.

[2] Bray, W. and D. Trump, (1975). The penguin dictionary of archaeology. Britain: The Penguin Press.

[3] Elochukwu Nwankwo (2014) Ethnoarchaeological Survey Of Obimo: A Fieldwork Report Department of Archaeology and Tourism, University of Nigeria, Nsukka Enugu State, Nigeria, journal of economy knowledge Vol.1, No2, pp 48-61

[4] Hester, T. R., R. F. Heinzer and J. M. Graham, (1975). Field methods in archaeology. UK: Mayfield Publishing Company.
[5] Igbo, E. U. M. \& Okpoko. P. U (2006) theoretical consideration in tourism planning and development" issue in tourism planning and development, Okpoko. P. U (ed). Nsukka: Afro-orbis publication, Co. Itd.

[6] Kay G. and Wright, D. M. (1962) 'Aspects of the Ushi iron industry', Northern Rhodesia Journal, V, 30-1.22

[7] Njoku, O. N., (2002). Indigenous science and technology in precolonial Nigeria: The examples of medicare and ironworking. In Nsukka Journal of the Humanities No. 12: 21-40.

[8] Nze, C. A., (2006). Excavation of an iron smelting site in Richard Ugwuoke's compound tagged, Ugwuoke Richard Obimo, 2006. A Fieldwork Report Submitted to the Department of Archaeology and Tourism University of Nigeria Nsukka.

[9] Ofomata, G. E. K., (1978). The Nsukka environment. In G. E. K. Ofomata (Ed). Enugu: Fourth Dimension Publishers.

[10] Okpoko, A. I., (1982). Ethnoarchaeological investigations in parts of Anambra valley. An Unpublished Ph.D. Thesis, University of Ibadan.

[11] Ozor, E. \& Francis, O. (2019). Ethnography of Affa kingdom interview oral tradition $25^{\text {th }} 03-2019$

[12] Nwafor, V. (2019). 'pottery production' interviewed oral tradition $25^{\text {th }}-03-2019$

[13] Whiteman, J. A. and E. E. Okafor, (2003). Characterization of Nigerian bloomery iron smelting slag. In Historical Metallurgy, 37(2). Available from http://cat.inist.fr/?amodel=affiche N\&cpsidt=15545214.

[14] Wilson, D., (1975). The new archaeology. New York: Knopf.

[15] http://www.comunsellcolorchart7.5yrdiagram

[16] http://www.fieldworkcatographicmapdigitalizationgislabart/ti mUNN. 